\title{
Jurisdiction and the Extraterritorial Application of Antitrust Laws after Hartford Fire
}

\author{
John A. Trenor $\dagger$
}

The overriding policy of the federal antitrust laws ${ }^{1}$ is to protect competition in U.S. markets. ${ }^{2}$ The Sherman Act, for example, prohibits restraints and monopolization or attempted monopolization of "trade or commerce among the several States, or with foreign nations." In an increasingly internationalized global economy, both domestic and foreign activities potentially threaten competition in U.S. markets. Congress, however, did not spell out the extent to which the federal antitrust laws were to reach anticompetitive activities occurring outside the United States. ${ }^{4}$ Neither the statutory language nor the legislative histo-

$\dagger$ B.A. 1991, Cornell University; M.P.A. 1995, The Woodrow Wilson School, Princeton University; J.D. 1995, The University of Chicago.

1 The federal antitrust laws, codified at 15 USC §§ 1 et seq (1988 \& Supp 1993), were enacted in a series of legislation beginning with the Sherman Act of 1890, 26 Stat 209, codified as amended at 15 USC $\$$ 1-7 (1988 \& Supp 1993), and the Clayton Act of 1914,38 Stat 730 , codified as amended at 15 USC $\$ \S 12-27$ (1988 \& Supp 1993). The Wilson Tariff Act of 1894, 28 Stat 509, 570, codified as amended at 15 USC $\$$ 8-11 (1988), regarding restraints on imports, is relevant as well, although its provisions are largely subsumed by the prohibitions of $\$ \S 1$ and 2 of the Sherman Act.

${ }^{2}$ See, for example, Northern Pacific Railway Co. v United States, 356 US 1, 4-5 (1958):

The Sherman Act was designed to be a comprehensive charter of economic liberty aimed at preserving free and unfettered competition as the rule of trade. It rests on the premise that the unrestrained interaction of competitive forces will yield the best allocation of our economic resources, the lowest prices, the highest quality and the greatest material progress, while at the same time providing an environment conducive to the preservation of our democratic political and social institutions.

315 USC $\S \S 1$, 2. Section 1 provides that "[e]very contract, combination ..., or conspiracy, in restraint of trade or commerce among the several States, or with foreign nations, is declared to be illegal." Section 2 provides that "[e]very person who shall monopolize, or attempt to monopolize, ... any part of the trade or commerce among the several States, or with foreign nations, shall be deemed guilty of a felony."

- Congress amended the federal antitrust laws with the Foreign Trade Antitrust Improvements Act of 1982 ("FTAIA"), Pub L No 97-290, 96 Stat 1246, codified at 15 USC $\S \S 6 \mathrm{a}, 45(\mathrm{a})$ (1988). This amendment more clearly specifies the scope of the antitrust laws regarding export trade, stating that the Sherman Act "shall not apply to conduct involving trade or commerce (other than import trade or import commerce) with foreign nations" 
ry of the antitrust laws provides any guidance as to the meaning of "commerce ... with foreign nations." This has left the task of determining the extraterritorial scope of the antitrust laws to federal courts.

While courts have generally agreed that the extraterritorial application of antitrust laws raises issues of international conflict of laws principles, courts have diverged considerably on two levels. First, courts have invoked different principles of international conflict of laws to resolve the extraterritoriality issue-evolving from strict territoriality to intended effects in the United States to a balancing of U.S. and foreign interests-to reflect the general development of international markets and the international system. ${ }^{5}$ Second, courts have disagreed more fundamentally on the characterization of the extraterritoriality analysis as a question of legislative jurisdiction or subject matter jurisdiction-that is, whether international conflict of laws principles circumscribe the power of Congress or the courts.

Traditionally, courts viewed international conflict of laws principles as limitations on Congress's power and as interpretive tools for ascertaining congressional purpose and intent. This characterization of the extraterritoriality analysis focused on legislative jurisdiction, asking whether Congress, in light of international conflict of laws principles, intended the laws to reach the conduct abroad. Breaking from prior understanding, however, the Ninth Circuit in Timberlane Lumber Co. $v$ Bank of Americ $a^{6}$ radically recharacterized the extraterritoriality analysis as one of subject matter jurisdiction, asking whether, in light of international conflict of laws principles, federal courts have the power to hear such extraterritorial cases. This revolution in characterization went unchallenged and was quiescently adopted by subsequent courts, including most recently the Supreme Court in Hartford Fire Insurance Co. $v$ California. ${ }^{7}$

This divergence in analytic characterization produces stark differences in both judicial analysis and procedure. Courts em-

unless such trade "has a direct, substantial, and reasonably foreseeable effect" on U.S. commerce. 15 USC $\S 6 a$. The FTAIA covers only export trade, however, and provides no guidance with respect to nonexport trade, such as trade in imports or domestic trade.

5 See Restatement (Third) of the Foreign Relations Law of the United States, Introductory Note to Part IV, ch 1, subch A at 237 (1987) ("Restatement of Foreign Relations"). See also Andreas F. Lowenfeld, Public Law in the International Arena: Conflict of Laws, International Law, and Some Suggestions for Their Interaction, 163 Recueil des Cours $311,373-411$ (1979).

6549 F2d 597 (9th Cir 1976).

7113 S Ct 2891 (1993). 
ploying the subject matter jurisdiction characterization are guided solely by notions of international comity and their own discretion. Courts would consider dismissal for lack of subject matter jurisdiction, which may be granted at any time, even on appeal, under FRCP 12(b)(1), whether on motion of a party or by the court sua sponte.

In sharp contrast, under the legislative jurisdiction characterization, courts engage in statutory construction, and courts' discretion is focused by efforts to ascertain congressional intent and purpose, subject to international conflict of laws principles. As for dismissal, parties must raise the issue of the nonapplicability of the federal antitrust laws, either on the pleadings under FRCP 12(b)(6) for failure to state a claim, before trial under FRCP 56 for summary judgment, or at a trial under FRCP 50 for directed verdict.

This Comment argues that courts should reassert the legislative jurisdiction characterization of the extraterritoriality analysis for both consistency and conceptual clarity. ${ }^{8}$ Section I outlines the various uses of the term "jurisdiction." Section II traces the development of the extraterritoriality analysis, both with respect to the international conflict of laws principles that courts have applied and with respect to the analytic characterizations that they have adopted. Section III analyzes the case law, first discussing the shortcomings of the traditional international conflict of laws principles, and second, exploring the flaws inherent in the subject matter jurisdiction analysis. Finally, Section IV proposes reestablishing the legislative jurisdiction analysis, yet updating the traditional analysis by incorporating more modern international conflict of laws principles.

\section{VARIOUS USES OF THE TERM "JURISDICTION"}

Much semantic confusion arises from the varying uses of the term "jurisdiction." Jurisdiction in the broadest sense of the term is the "authority of a sovereign power to govern." This authority to govern is divided in the United States first by our federal system between the federal and state governments and second

a This Comment attempts to resolve the characterization debate. Reasserting the legislative jurisdiction characterization has significant procedural ramifications as well, stemming from the distinction between FRCP 12(b)(1) and 12(b)(6). See text accompanying note 150.

9 Webster's Third New International Dictionary of the English Language, Unabridged 1227 (Merriam-Webster, 1986). 
through the separation of powers among the three branches of federal government: the legislature, the executive, and the judiciary. The U.S. Constitution delineates the competences of the several branches ${ }^{10}$ and of the federal and state governments. ${ }^{11}$ Governing, of course, encompasses several dimensions: the authority to prescribe laws, the authority to subject persons and things to appear before courts and tribunals, and the authority to enforce laws. ${ }^{12}$ Thus, the broad notion of jurisdiction may be divided into three subcategories: legislative (or prescriptive) jurisdiction, judicial jurisdiction, and jurisdiction to enforce. ${ }^{13}$

Legislative jurisdiction is the authority of a nation-state to make its laws applicable to persons or activities. ${ }^{14}$ Article I of the Constitution delimits Congress's authority to exercise legislative jurisdiction. ${ }^{15}$ In enacting the federal antitrust laws, Congress exercised its grant of legislative jurisdiction to regulate interstate and foreign commerce. ${ }^{16}$ Often, however, as in the case of the federal antitrust laws, the reach or extent of legislation is not clear on the face of the statute. Consequently, courts are left with the task of interpreting these statutes to determine the extent to which Congress has exercised its legislative jurisdiction in its prescription of the law. This often involves probing

10 See US Const, Arts I-III.

11 See US Const, Arts I, VI; US Const, Amend X.

12 Restatement of Foreign Relations, Introductory Note to Part IV at 230 (cited in note 5).

13 Because the functions of legislating, adjudicating, and enforcing the laws do not perfectly coincide with the roles of Congress, the federal Judiciary, and the Executive in the modern regulatory state, the Restatement of Foreign Relations recommends use of the terms jurisdiction to prescribe, jurisdiction to adjudicate, and jurisdiction to enforce. Id at 231. However, because this Comment deals exclusively with purely legislative and judicial functions exercised by Congress and the courts, respectively, it will employ the more common terms "legislative jurisdiction" and "judicial jurisdiction" throughout.

While not within the scope of this Comment, issues concerning the exercise of jurisdiction to enforce often arise in the context of the extraterritorial application of antitrust laws. See generally Gary B. Born and David Westin, International Civil Litigation in United States Courts: Commentary and Materials 319-41, 351-405 (Kluwer, 2d ed 1992). See also Restatement of Foreign Relations $\S 431$ (cited in note 5) (discussing jurisdiction to enforce).

14 See Restatement of Foreign Relations $\$ 401$ (cited in note 5). See also Born and Westin, International Civil Litigation at 541.

${ }_{15}$ Congress also derives legislative jurisdiction from other provisions of the Constitution. See, for example, US Const, Amend XIV, § 5. Other provisions of the Constitution, such as the Bill of Rights, place further limits on such exercise of legislative jurisdiction. For example, see Lea Brilmayer and Charles Norchi, Federal Extraterritoriality and Fifth Amendment Due Process, 105 Harv L Rev 1217 (1992) (discussing the limitations of due process on extraterritoriality).

16 See US Const, Art I, § 8, cl 3 (Congress shall have power “[t]o regulate Commerce with foreign Nations, and among the several States . ....). 
the intent and purpose of Congress, and courts have used numerous interpretive tools to derive this intent from statutes. Foremost among these interpretive tools in the extraterritoriality context is the canon of statutory construction that presumes that Congress did not intend to violate principles of international law. ${ }^{17}$

Judicial jurisdiction is the power of courts to subject particular persons or things to the judicial process. ${ }^{18}$ However, courts may not exercise judicial jurisdiction unless the courts also have "subject matter jurisdiction," that is, the power to hear particular categories of cases. ${ }^{19}$ Article III of the Constitution establishes the "judicial Power of the United States" and delimits the categories of cases open to federal courts' subject matter jurisdiction. ${ }^{20}$ Federal questions compose the most important of these constitutional categories of cases with respect to antitrust law: cases arising under the Constitution and laws of the United States. ${ }^{21}$

17 This oft-cited maxim was first expressed by Chief Justice Marshall in Murray $v$ Schooner Charming Betsy, 6 US (2 Cranch) 64, 118 (1804) ("[A]n Act of Congress ought never to be construed to violate the law of nations if any other possible construction remains ...."). See also Restatement of Foreign Relations $\S 114$ (cited in note 5) ("Where fairly possible, a United States statute is to be construed so as not to conflict with international law or with an international agreement of the United States."). This canon of statutory construction is commonly employed by U.S. courts. See, for example, Lauritzen $v$ Larsen, 345 US 571, 578 (1953). See also Hartford Fire, 113 S Ct at 2919 (Scalia dissenting).

${ }^{18}$ See Restatement of Foreign Relations $\$ 401$ (cited in note 5); Charles A. Wright and Arthur R. Miller, Federal Practice and Procedure $\$ 1351$ at 239-61 (West, 2d ed 1990) (discussing FRCP 12(b)(2)). This aspect of judicial jurisdiction is more commonly termed "personal jurisdiction" when in reference to subjecting particular persons, and "in rem jurisdiction" when in reference to subjecting particular things to the judicial process. Personal jurisdiction is the power of a court to adjudicate a claim against the defendant's person. See Wright and Miller, Federal Practice and Procedure $\$ 1351$ at 239-45. Establishing personal jurisdiction over the defendant is of central importance in extraterritorial antitrust cases involving foreign defendants. Courts generally look to whether the defendant has some reasonable relationship with the United States. See International Shoe Co. $v$ Washington, 326 US 310, 316 (1945) (Due process requires that a defendant have "certain minimum contacts" with the forum state such that "the maintenance of the suit does not offend 'traditional notions of fair play and substantial justice."). See generally Born and Westin, International Civil Litigation at 27-152 (cited in note 13).

${ }_{19}$ See Wright and Miller, Federal Practice and Procedure $\$ 1350$ at 194-96 (discussing FRCP 12(b)(1)).

${ }^{20}$ US Const, Art III, $\S \S 1,2$.

${ }^{21}$ Id. The U.S. government may also be a party to an antitrust case, thereby providing an independent basis for subject matter jurisdiction: "Controversies to which the United States shall be a Party .... ${ }^{n}$ Id. See 28 USC $\$ 1345$ (1988), in which Congress has granted subject matter jurisdiction to federal courts in all cases "commenced by the United States or by any agency or officer thereof expressly authorized to sue by Act of Congress." 
Federal subject matter jurisdiction, however, depends not only on this constitutional source, but on congressional enactments as well. ${ }^{22}$ As for the federal antitrust laws, several congressional enactments of subject matter jurisdiction are relevant. Most generally, 28 USC $\S 1331$ grants federal courts subject matter jurisdiction for cases "arising under" federal law or the Constitution. ${ }^{23}$ More specifically, 28 USC $\S 1337$ grants federal courts subject matter jurisdiction for cases "arising under" the federal antitrust laws. ${ }^{24}$ Moreover, in enacting the Sherman and Clayton Acts, Congress also specifically provided for federal court subject matter jurisdiction, such as in 15 USC $\S 15,{ }^{25}$ distinct from the substantive prohibitions on restraints of trade and monopolization. Thus, there are three independent statutory sources of federal court subject matter jurisdiction for cases arising under the federal antitrust laws. ${ }^{26}$

While the concepts of legislative and subject matter jurisdiction are theoretically distinct, much confusion has arisen with respect to the extraterritorial application of the antitrust laws. In

${ }_{22}$ US Const, Art III, \& 1 provides: "The judicial Power of the United States, shall be vested in one supreme Court, and in such inferior Courts as the Congress may from time to time ordain and establish." Subject matter jurisdiction of the lower federal courts therefore requires both a constitutional and a statutory basis. See Louisville and Nashville Railroad Co. $v$ Mottley, 211 US 149, 152-53 (1908). Known as 'Madison's Compromise," this constraint was a conscious compromise by the Framers of the Constitution to balance the interests of the federal government and the several states. See generally Paul M. Bator, et al, Hart and Wechsler's The Federal Courts and the Federal System 1-30 (Foundation, 3d ed 1988). Accordingly, federal courts would have the power to hear cases only in limited categories of cases, while state courts would have much more general subject matter jurisdiction. See US Const, Art III, § 2, cl 1. In the extraterritorial antitrust context, the dispute is not which courts, federal or state, have subject matter jurisdiction; federal courts have exclusive subject matter jurisdiction over federal antitrust cases (as opposed to concurrent subject matter jurisdiction with state courts). See Blumenstock Brothers Advertising Agency v Curtis Publishing Co., 252 US 436, 440-41 (1920). Therefore, the dispute is whether any U.S. court will have subject matter jurisdiction to hear the case.

${ }_{23} 28$ USC $\S 1331$ (1988) (establishing federal subject matter jurisdiction over "all civil actions arising under the Constitution, laws, or treaties of the United States").

${ }^{24} 28$ USC \& 1337 (1988) (establishing federal subject matter jurisdiction over "any civil action or proceeding arising under any Act of Congress regulating commerce or protecting trade and commerce against restraints and monopolies").

${ }_{25}$ See 15 USC $\S 15$ (creating private actions for treble damages in federal district court). See also id $\S 26$ (creating private actions for injunctive relief). Compare id $\S \S 4,9$ (authorizing the U.S. attorneys to institute antitrust actions on behalf of the U.S. government).

${ }^{26}$ The seemingly superfluous provisions in the Sherman and Clayton Acts, as well as the provision in 28 USC $\S 1337$, can be explained by the recently abolished "amount in controversy" requirement of $\S 1331$ general federal question jurisdiction. See 28 USC $\S$ 1331 (Historical and Revision Notes). 
enacting the Sherman and Clayton Acts, Congress simultaneously prescribed substantive rules for the regulation of competition $^{27}$ (an exercise of legislative jurisdiction) and granted federal courts the power to hear cases arising under these substantive provision $^{28}$ (a grant of subject matter jurisdiction). ${ }^{29}$ As a result of this dual nature of the federal antitrust laws, courts have ruled inconsistently on whether to frame the extraterritoriality analysis as a question of legislative or subject matter jurisdiction.

\section{The DeVElopment of THE ExTRATERRITORIALITY ANALYSIS}

The extraterritorial antitrust case law exhibits two trends: first, an evolution in the principles of international conflict of laws that courts have recognized, and second, a revolution in the analytic characterization under which these principles are applied.

\section{A. The Evolution of International Conflict of Laws Principles}

1. Strict territoriality.

The Supreme Court first addressed the question of the extraterritorial application of the Sherman Act in American Banana Co. $v$ United Fruit Co ${ }^{30}$ Adopting the strict territoriality principle of international conflict of laws, Justice Holmes, speaking for the Court, held: "[T]he general and almost universal rule is that the character of an act as lawful or unlawful must be determined wholly by the law of the country where the act is done. ${ }^{31}$ Justice Holmes concluded that the strict territoriality principle confined the reach of the Sherman Act, ${ }^{32}$ and he unequivocally denounced the extraterritorial application of U.S. law:

For another jurisdiction, if it should happen to lay hold of the actor, to treat him according to its own notions rather than those of the place where he did the acts, not only would be unjust, but would be an interference with the authority of

27 See, for example, 15 USC $\S \S 1,2$.

$2 s$ See id $\$ \$ 4,9,15,26$.

29 See Hartford Fire, $113 \mathrm{~S}$ Ct at 2909 n 22, quoting Born and Westin, International Civil Litigation at $542 \mathrm{n} 5$ (cited in note 13) (The federal antitrust laws are "prime examples of the simultaneous exercise of prescriptive [or legislative] jurisdiction and grant of subject matter jurisdiction.").

3o 213 US 347 (1909).

31 Id at 356.

32 Id at 357-58. 
another sovereign, contrary to the comity of nations, which the other state concerned justly might resent. ${ }^{33}$

Courts soon showed dissatisfaction with the strict territoriality principle and began to relax the holding of American Banana. For example, in United States $v$ Sisal Sales Corp, the Supreme Court upheld the application of the Sherman Act to a monopoly in the foreign supply and importation of sisal into the United States. ${ }^{34}$ The Court distinguished American Banana by contending that " $[\mathrm{h}]$ ere we have a contract, combination, and conspiracy entered into by the parties within the United States and made effective by acts done therein." ${ }^{35}$ The Court sidestepped the strict territoriality principle by pointing to some activity carried out within the United States. ${ }^{36}$

\section{2. "Intended effects."}

Courts abandoned the strict territoriality principle following the seminal decision by Judge Learned Hand of the Second Circuit in United States $v$ Aluminum Co. of America ("Alcoa"). ${ }^{37}$ Judge Hand observed that courts "are not to read general words, such as those in [the Sherman] Act, without regard to the limitations customarily observed by nations upon the exercise of their powers; limitations which generally correspond to those fixed by the 'Conflict of Laws."'38 Building on the gradual erosion of the strict territoriality principle, Judge Hand ultimately dispensed with the American Banana test and, in its place, espoused an "effects" test: acts outside the United States were said to be prohibited by the Sherman Act "if they were intended to affect imports and did affect them."39

33 Id at 356.

274 US 268, 276 (1927).

${ }^{35}$ Id.

${ }^{36}$ Id. For other cases evincing the gradual erosion of the strict territoriality principle, see United States v Pacific \& Arctic Railway \& Navigation Co., 228 US 87, 105-06 (1913) (Even though the conspiracy involved foreign parties, "it was a control to be exercised over transportation in the United States, and, so far, is within the jurisdiction of the laws of the United States...."); Thomsen. $v$ Cayser, 243 US 66, 88 (1917) (Although the combination was formed abroad, "the combination affected the foreign commerce of this country and was put into operation here. ... It, therefore, is within the law ....").

${ }^{37} 148$ F2d 416 (2d Cir 1945). Alcoa was certified by the Supreme Court to the Second Circuit, as the Supreme Court could not muster a quorum of six Justices qualified to hear the case. Id at 421 . Thus, while technically a Second Circuit opinion, Judge Hand's decision has carried additional influence among courts.

${ }^{38}$ Id at 443.

${ }^{39}$ Id at 444. The Alcoa test is commonly referred to as the "intended effects" test, or 
The Alcoa "intended effects" test quickly garnered wide support by courts, including the Supreme Court. The Supreme Court itself rejected the strict territoriality principle in favor of the more expansive effects test in Continental Ore Co. $v$ Union Carbide \& Carbon Corp. ${ }^{40}$ The Court held that "in light of later cases in this Court [defendants'] reliance upon American Banana is misplaced. ${ }^{\$ 1}$

\section{Interest balancing and the "jurisdictional rule of reason."}

While courts and commentators saw Justice Holmes's strict territoriality principle in American Banana as too narrow, they soon criticized Judge Hand's "intended effects" principle in Alcoa as being too broad. ${ }^{42}$ In Timberlane, the Ninth Circuit recognized the criticisms of the Alcoa effects test, namely that it fails to consider other nations' interests. ${ }^{43}$ Understanding the role of international conflict of laws in the extraterritoriality analysis, ${ }^{44}$ Timberlane was innovative because of its explicit recognition of international comity, asking: "whether the interests of, and links to, the United States-including the magnitude of the effect on American foreign commerce-are sufficiently strong, vis-à-vis those of other nations, to justify an assertion of extraterritorial authority. ${ }^{345}$ Furthermore, Timberlane provided a list of factors

even more simply as the "effects" test. Interestingly, Judge Hand stated that after intent to affect imports is proven, the burden of proof shifts to the defendant to demonstrate insufficient effects in the United States. Id.

40 370 US 690 (1962). Prior to Hartford Fire, however, the Court had never explicitly overruled the strict territoriality holding of American Banana.

11 Id at 704. The Court went on to hold that "[a] conspiracy to monopolize or restrain the domestic or foreign commerce of the United States is not outside the reach of the Sherman Act just because part of the conduct complained of occurs in foreign countries." Id, citing, among others, Pacific \& Arctic Railway, 228 US 87; Thomsen, 243 US 66; Sisal, 274 US 268.

${ }^{42}$ See, most notably, Kingman Brewster, Antitrust and American Business Abroad § 15.2 at $445-46$ (McGraw-Hill, 1st ed 1958).

43549 F2d at 609 ("In any event, it is evident that at some point the interests of the United States are too weak and the foreign harmony incentive for restraint too strong to justify an extraterritorial assertion of jurisdiction.").

11 Id at 613 ("We believe that the field of conflict of laws presents the proper approach, as was suggested, if not specifically employed, in Alcoa in expressing the basic limitation on application of American laws.").

45 Id. Although Kingman Brewster had advocated balancing U.S. and foreign interests some twenty years before, Antitrust and American Business Abroad $\$ 15.2$ at 446 , his "jurisdictional rule of reason" did not receive judicial endorsement until Timberlane, 549 F2d at 613-614 ("What we prefer is an evaluation and balancing of the relevant considerations [foreign interests] in each case-in the words of Kingman Brewster, a jurisdictional rule of reason."). Elsewhere, the court referred to the balancing as a "reconciliation of American and foreign interests in regulating their respective economies and business 
to guide the court in determining whether to apply the antitrust laws extraterritorially. ${ }^{46}$

Timberlane's use of international comity, also known as the "jurisdictional rule of reason," ${ }^{\text {"47 }}$ or interest balancing, received much fanfare and was quickly adopted with modifications by numerous courts. ${ }^{48}$ The interest-balancing approach first adopted by the Timberlane court was eventually incorporated into the most recent edition of the Restatement of Foreign Relations. ${ }^{49}$ Section 403 of the Restatement identifies a nonexhaustive list of factors, similar to those cited by Timberlane and other cases, which the field of international conflict of laws recognizes as establishing reasonable extraterritorial application. ${ }^{50}$

B. The Revolution in the Characterization of the Extraterritoriality Analysis

While this historical review of the case law demonstrates a gradual (and ongoing) evolution of international conflict of laws principles, courts' use of these principles-by focusing either on a legislative jurisdiction or a subject matter jurisdiction characterization-manifested a stark divergence from precedent beginning with the Ninth Circuit in Timberlane, which subsequent courts have followed without question. The early cases, from American

affairs." Id at 611, quoting Note, American Adjudication of Transnational Securities Fraud, 89 Harv L Rev 553, 556 (1976).

${ }^{46}$ Timberlane, 549 F2d at 614-15. Specifically, the Timberlane court identified seven factors to be weighed:

(1) the degree of conflict with foreign law or policy,

(2) the nationality or allegiance of the parties and the locations or principal places of business of corporations,

(3) the extent to which enforcement by either state can be expected to achieve compliance,

(4) the relative significance of effects on the United States as compared with those elsewhere,

(5) the extent to which there is explicit purpose to harm or affect American commerce,

(6) the foreseeability of such effect, and

(7) the relative importance to the violations charged of conduct within the United States as compared with conduct abroad.

Id at 614 .

47 See Brewster, Antitrust and American Business Abroad $\S 15.2$ at 446 (cited in note 42).

48 See, for example, Mannington Mills, Inc. $v$ Congoleum Corp, 595 F2d 1287, 1297-98

(3d Cir 1979) (identifying a list of ten similar factors).

49 Restatement of Foreign Relations $\S 403$ (cited in note 5).

${ }^{50}$ Id. Compare the Timberlane factors quoted in note 46. 
Banana to Alcoa and beyond, framed the extraterritoriality analysis as one of legislative jurisdiction, while Timberlane and its progeny introduced an entirely new analysis, one of subject matter jurisdiction.

1. The legislative jurisdiction characterization.

The legislative jurisdiction characterization focuses on whether Congress intended the antitrust laws to apply to anticompetitive conduct abroad. ${ }^{51}$ In ascertaining congressional intent and purpose to regulate extraterritorial conduct, courts take into consideration principles of international conflict of laws, under the presumption that Congress did not intend to violate the limitations imposed by international law on legislative jurisdiction, absent a contrary expression. This canon of statutory interpretation has long been used by courts to define the extraterritorial reach of the federal antitrust laws. Indeed, the antitrust precedents, at least before Timberlane, strongly support this legislative jurisdiction characterization of the extraterritoriality analysis.

Beginning with the Court's first decision on the extraterritorial reach of the antitrust laws in American Banana, the Court consistently adhered to a legislative jurisdiction analysis. Justice Holmes in American Banana spoke unequivocally in terms of legislative jurisdiction: "The foregoing considerations would lead in case of doubt to a construction of any statute as intended to be confined in its operation and effect to the territorial limits over which the lawmaker has general and legitimate power. 'All legislation is prima facie territorial." ${ }^{m 2}$ Applying the international conflict of laws principle of strict territoriality to guide his interpretation of the Sherman Act's application to conduct abroad, Justice Holmes concluded that "what the defendant did [abroad] is not within the scope of the statute so far as the present suit is concerned. ${ }^{.53}$ Holmes, therefore, dismissed the complaint, not for want of subject matter jurisdiction, but for failure to state a claim. ${ }^{54}$

st Many courts have framed the analysis in terms of legislative jurisdiction. See, for example, American Banana, 213 US at 357 (applying a conflict of laws principle of strict territoriality); Alcoa, 148 F2d at 443-44 (applying a conflict of laws principle of "intended effects"). See also Hartford Fire, 113 S Ct at 2918-22 (Scalia dissenting) (applying a conflict of laws principle of international comity).

$52 \quad 213$ US at 357.

$\$ 3$ Id.

s4 Id at 359. 
Like the Court in American Banana, subsequent Courts before Alcoa did not question the power of federal courts to hear extraterritorial cases, but rather ascertained the scope of legislative jurisdiction, that is, whether the plaintiff stated a cause of

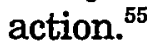

In Alcoa, which essentially refuted the strict territoriality principle, Judge Hand of the Second Circuit similarly applied a legislative jurisdiction analysis. ${ }^{56}$ Citing such sources as the Restatement (First) of Conflict of Laws on "legislative jurisdiction, ${ }^{357}$ Judge Hand repeatedly characterized his role as ascertaining whether Congress intended the Sherman Act to cover the extraterritorial activities, refusing to impute to Congress an intent to violate international conflict of laws rules. ${ }^{58}$ Like American Banana, Alcoa assumed that Congress intended to respect the limits on legislative jurisdiction imposed by international conflict of laws principles and international comity. Alcoa merely reflected the more current international conflict of laws principle of the "effects" test. Neither Justice Holmes in American Banana nor Judge Hand in Alcoa disputed the power of federal courts to hear extraterritorial cases. ${ }^{59}$

2. The subject matter jurisdiction characterization.

Prior to the Ninth Circuit's decision in Timberlane, which ushered in the interest-balancing principle of international conflict of laws, courts had without exception analyzed the extraterritorial application of the antitrust laws as a question of legislative jurisdiction. Unlike these prior cases, however, Timberlane

${ }_{55}$ See, for example, United States $v$ Pacific \& Arctic Railway \& Navigation Co., 228 US 87, 105-06 (1913); Thomsen v Cayser, 243 US 66, 88 (1917); Sisal Sales Corp, 274 US at 276.

${ }^{56} 148 \mathrm{~F} 2 \mathrm{~d}$ at 443 ("[W]e are concerned only with whether Congress chose to attach liability to the conduct outside the United States of persons not in allegiance to it. That being so, the only question open is whether Congress intended to impose the liability, and whether our own Constitution permitted it to do so ....").

${ }^{57}$ Id, citing Strassheim v Daily, 221 US 280, 284-85 (1911); Lamar v United States, 240 US 60, 65-66 (1916); Ford v United States, 273 US 593, 620-21 (1927); Restatement (First) of Conflict of Laws $\$ 65$ (1934).

ss 148 F2d at 443 ("We should not impute to Congress an intent to punish all whom its courts can catch, for conduct which has no consequences within the United States.").

59 Indeed, no extraterritorial antitrust cases prior to Timberlane questioned the court's subject matter jurisdiction. But, as noted below, many subsequent courts have recharacterized the Alcoa effects principle as a test for establishing subject matter jurisdiction. See, for example, Timberlane, 549 F2d at 613-14; Mannington Mills, Inc. $v$ Congoleum Corp, 595 F2d 1287, 1297-98 (3d Cir 1979); and most importantly Hartford Fire, $113 \mathrm{~S}$ Ct at 2908-10. 
radically recharacterized the extraterritoriality analysis as one of subject matter jurisdiction, or the power of the federal courts to hear such cases. ${ }^{60}$

While the legislative jurisdiction characterization focuses on judicial interpretation of congressional intent and purpose, the subject matter jurisdiction characterization focuses exclusively on the power of the court to hear the case. There are two variants of the subject matter jurisdiction characterization. The court in Timberlane assumed a one-pronged subject matter jurisdiction analysis of extraterritoriality, lumping several factors into its determination. Timberlane transformed the Alcoa effects test into a basis for subject matter jurisdiction and added an additional requirement, interest balancing. ${ }^{61}$ Thus, the court held that it would consider both the effects on commerce and notions of international comity in determining the court's judicial power to hear the case. ${ }^{62}$

The second variant of the subject matter jurisdiction characterization assumes a two-pronged analysis. This adaptation of the Timberlane approach is illustrated by Mannington Mills, Inc. $v$ Congoleum Corp. ${ }^{63}$ Whereas Timberlane seemed to make both the effects test and international comity requisites for establishing subject matter jurisdiction, Mannington Mills separated the effects test from international comity considerations in a twopronged subject matter jurisdiction analysis. First, Mannington Mills stated that subject matter jurisdiction is based upon Alcoa's "intended effects" test. ${ }^{64}$ Second, if subject matter jurisdiction is found to exist, Mannington Mills held that the court must decide,

${ }^{60}$ See Timberlane, $549 \mathrm{~F} 2 \mathrm{~d}$ at $613 \mathrm{n} 27$. "[J]urisdictional' forebearance in the international setting is more a question of comity and fairness than one of national power." Compare Brewster, Antitrust and American Business Abroad $\S 15.2$ at 446 (cited in note 42). Timberlane adopted a subject matter jurisdiction characterization despite recognizing that because the Sherman Act does not "limit itself," "courts have generally, and logically, fallen back on a narrower construction of congressional intent, such as expressed in Judge Learned Hand's oft-cited opinion in Alcoa." Timberlane, 549 F2d at 609 (citation omitted). This remark, however, would suggest applying a legislative jurisdiction analysis.

61 Timberlane, 549 F2d at 613-14.

62 James R. Atwood and Kingman Brewster advocate this one-pronged subject matter jurisdiction analysis of extraterritoriality as the appropriate characterization: "In our view, the balancing process should be an integral part of the jurisdictional issue. This appears to have been the Timberlane court's intent." See James R. Atwood and Kingman Brewster, Antitrust and American Business Abroad $\$ \S 6.13-6.14$ at 166-68 (McGraw Hill, $2 d$ ed 1981) (evincing a concern not to "embroil [these cases] in litigation in American courts").

63 595 F2d 1287 (3d Cir 1979).

GA Id at 1291-92. 
using notions of international comity, "whether jurisdiction should be exercised [or declined]."165

Whether one- or two-pronged, the subject matter jurisdiction characterization thoroughly reframed the extraterritoriality analysis from a limitation on the power of Congress to regulate certain extraterritorial conduct to a limitation on the power of the federal courts to hear certain extraterritorial cases. ${ }^{66}$ In the torrent of attention that Timberlane's adoption of the interest-balancing test received, the court's recharacterization of the analysis as one of subject matter jurisdiction went unnoticed and unchallenged. Many courts adopted the "jurisdictional rule of reason" and Timberlane's subject matter jurisdiction recharacterization without questioning the fundamental recharacterization that the Timberlane court assumed. ${ }^{67}$

\section{Hartford Fire Muddies the Waters-Where Are We Now?}

The Supreme Court recently stepped into the fray in Hartford Fire. There, the Court split sharply, five to four, over what international conflict of laws principle to apply in antitrust cases and even more fundamentally over how to characterize the extraterritoriality analysis-as a question of the power of courts or Congress. ${ }^{68}$

65 Id at 1290, 1294 (emphasis added). Demonstrating much of the confusion surrounding the divergent characterizations of the extraterritoriality analysis, the dissent in Mannington Mills denounced using discretion in the exercise of subject matter jurisdiction as the majority's two-pronged analysis counseled. Id at 1299 (Adams dissenting). Instead, the dissent contended that international comity considerations "are properly to be weighed at the outset when the court determines whether jurisdiction vel non exists." Id. Thus, the dissent harked back to the Timberlane one-pronged analysis, incorporating comity into the subject matter jurisdiction determination. Id at 1299-1300. The dissent went so far as to argue that "a final determination as to the existence of subject-matter jurisdiction must often await some clarification of the substantive offense." Id at 1300 .

Nonetheless, several courts have subsequently adopted the majority's position. See In re Uranium Antitrust Litigation, 617 F2d 1248, 1253 (7th Cir 1980) ("We view the jurisdictional issue as two-pronged: (1) does subject matter jurisdiction exist; and (2) if so, should it be exercised?"); Montreal Trading Ltd. v Amax Inc., 661 F2d 864, 869 (10th Cir 1981).

66 That the Timberlane court made such a significant recharacterization of the underlying extraterritoriality analysis without so much as acknowledging this revolution, let alone attempting to justify the shift, supports the speculation that the departure initially may have been semantic in nature. Due to the important conceptual and procedural implications that such a recharacterization demands of courts, one would expect closer scrutiny on the part of a court intending to embark on such a major shift in analysis.

${ }_{67}$ See, for example, Mannington Mills, 595 F2d at 1297-98; Uranium Antitrust, 617 F2d at 1255; Montreal Trading, 661 F2d at 869.

68 Interestingly, both the majority opinion by Justice Souter and the dissenting opinion by Justice Scalia relied on the Restatement of Foreign Relations in support of 
Justice Souter, writing for the majority, assumed a subject matter jurisdiction analysis (a two-pronged test like that of the Mannington Mills court), yet he offered little justification or defense of this approach. ${ }^{69}$ Souter stated that the district court "undoubtedly" had subject matter jurisdiction based on Alcoa's "intended effects" test, to which he added a requirement of "substantial effect in the United States."70 Framing the analysis as one of whether to decline subject matter jurisdiction seems to have heavily influenced the international conflict of laws principle that Souter applied. ${ }^{71}$ Courts generally hesitate to decline to exercise subject matter jurisdiction; accordingly, Souter held that notions of international comity are appropriately considered (declining subject matter jurisdiction under the test's second prong), if at all, only where "there is in fact a true conflict between domestic and foreign law." ${ }^{\text {" }}$ By declaring that there is no "true conflict" unless a person is subject to inconsistent legislation by two nation-states, both of whose laws cannot be complied with simultaneously, Souter anxiously avoided the international comity issue of whether to decline subject matter jurisdiction. ${ }^{73}$

their extraterritoriality analyses. See Hartford Fire, 113 S Ct at 2909-11, 2918-22. However, while citing to this same source to buttress their characterizations of the extraterritoriality analysis, the majority and dissent arrived at remarkably divergent conclusions.

69 Id at 2909-10 \& $n$ 24. Justice Souter relied on Mannington Mills and Alcoa to support this contention. However, this reliance on Alcoa is particularly perplexing given the legislative jurisdiction characterization that Judge Hand adopted in Alcoa. See Alcoa, 148 F2d at 443-44. Justice Souter's footnotes in Hartford Fire also suggest that he misunderstood Justice Scalia's dissent advocating legislative jurisdiction. See Hartford Fire, $113 \mathrm{~S}$ Ct at 2909-11 nn 22, 24, 25. In adopting the two-pronged subject matter jurisdiction analysis of Mannington Mills, Justice Souter apparently assumed that Justice Scalia was advocating a one-pronged subject matter jurisdiction analysis like that of Timberlane, rather than the legislative jurisdiction analysis that Scalia actually urged. See id at 2909 n 24 ("Justice Scalia contends that comity concerns figure into the prior analysis whether jurisdiction exists under the Sherman Act.").

${ }^{70}$ Id at 2909. Again, like the courts in Timberlane and Mannington Mills, Souter used Alcoa's "intended effects" as a test for subject matter jurisdiction, although in Alcoa itself Judge Hand used a legislative jurisdiction characterization. See text accompanying notes 56-59.

71 Justice Souter actually reserved opinion on whether courts could ever decline to exercise subject matter jurisdiction once established under the "intended effects" test of Alcoa (the first prong of Mannington Mills). Hartford Fire, $113 \mathrm{~S}$ Ct at 2910.

72 Id.

73 Id at 2910-11. Notably, Justice Souter's use of the term "true conflict," originally coined by Brainerd Currie, differs considerably from Currie's original meaning. Currie's use of the term implied a conflict of two or more states' legislative policies, such that each state's legislative policies would be furthered by application of that state's law. See, for example, Brainerd Currie, Selected Essays on Conflict of Laws 80-81, 107-17 (1963). Souter's new meaning requires an impossibility of abiding by two different states' legislation; conflicting legislative policies are not sufficient to raise a "true conflict" concern if the 
Thus, while Souter's "true conflict" limitation represented a dramatic regression with regard to the international conflict of laws principle invoked-away from interest balancing back to "intended effects"-his analytic characterization of the extraterritoriality analysis as a question of subject matter jurisdiction followed Mannington Mills.

Justice Scalia in dissent advocated a diametrically opposed analytic characterization, one of legislative jurisdiction. Scalia argued: "It is important to distinguish two distinct questions raised by this petition: whether the District Court had jurisdiction, and whether the Sherman Act reaches the extraterritorial conduct alleged here."74 As for the first question, Scalia asserted that subject matter jurisdiction exists for all nonfrivolous claims under 28 USC $\S 1331$, which vests district courts with subject matter jurisdiction over cases "arising under" federal statutes. ${ }^{75}$ As for the second question, Scalia argued that the extraterritorial reach of the Sherman Act "has nothing to do with the jurisdiction of the courts. It is a question of the substantive law turning on whether, in enacting the Sherman Act, Congress asserted regulatory power over the challenged conduct." ${ }^{76}$ Thus, in Scalia's view, the extraterritoriality analysis is one of legislative jurisdiction, or "the authority of a state to make its law applicable to persons or activities," a question theoretically distinct from the power of the court to hear the case. ${ }^{77}$

Scalia employed two canons of statutory construction to assist in this determination of the extent to which Congress has exercised its legislative jurisdiction: first, a presumption against extraterritoriality, and second, a presumption that Congress did not intend to violate principles of international law. ${ }^{78}$ Scalia re-

defendant can abide by the proscriptions of the laws themselves. Hartford Fire, $113 \mathrm{~S} \mathrm{Ct}$ at 2910-11.

${ }^{74}$ Hartford Fire, $113 \mathrm{~S}$ Ct at 2917 (Scalia dissenting).

75 Id. Notably, Justice Scalia did not mention the Alcoa effects test in his dissent.

76 Id at 2918.

nI. Id. Because the Sherman Act's extraterritorial reach is ambiguous from the language of the statute and the legislative history, Justice Scalia asserted that "the question in this case is whether, and to what extent, Congress has exercised that undoubted legislative jurisdiction in enacting the Sherman Act." Id.

${ }^{78}$ Id at 2918-19. Justice Scalia cited EEOC v Arabian American Oil Co., 499 US 244, 248 (1991) ("Aramco"), as support for the presumption against extraterritoriality: "[L]egislation of Congress, unless a contrary intent appears, is meant to apply only within the territorial jurisdiction of the United States." Justice Scalia cited Murray $v$ Schooner Charming Betsy, 6 US (2 Cranch) 64, 118 (1804), as support for the international law presumption: "[A]n act of Congress ought never to be construed to violate the law of nations if any other possible construction remains." 
luctantly conceded that precedent had established that the territorial presumption of the Sherman Act has been overcome. ${ }^{79}$ According to Scalia, however, the international law presumption "is relevant to determining the substantive reach of a statute because 'the law of nations,' or customary international law, includes limitations on a nation's exercise of its [legislative jurisdiction,] ... [which] Congress is generally presumed not to have exceeded."80 Using this international law presumption, Scalia argued that U.S. courts should interpret the scope of the antitrust laws consonant with the principles of international conflict of laws and international comity. ${ }^{81}$

The majority opinion of Justice Souter in Hartford Fire ostensibly held that the prevailing international conflict of laws principle that courts must apply is Alcoa's "intended effects" test (turned up a notch to "substantial effects"), at least in the absence of what Souter termed a "true conflict." However, the precedential force of this holding was tempered considerably by numerous qualifications. ${ }^{83}$ Moreover, while the Hartford Fire majority assumed a subject matter jurisdiction characterization, the characterization issue was not directly before the Court and not definitively decided. Rather, the Souter majority unquestioningly presupposed a subject matter jurisdiction analysis in the course of resolving the issue directly before the Court: whether the antitrust laws applied to defendants' conduct abroad. Thus, the dispute between the majority and the dissent has provided little guidance for lower courts on the characterization debate. ${ }^{84}$

79 Notably citing Continental Ore, 370 US 690, and Alcoo, 148 F2d 416, for this proposition. Hartford Fire, $113 \mathrm{~S} \mathrm{Ct}$ at 2918-19.

${ }^{80}$ Hartford Fire, $113 \mathrm{~S}$ Ct at 2919.

81 Id at 2919-20. The comity to which Justice Scalia refers is "not the comity of courts . . . but rather what might be termed 'prescriptive comity' [or legislative comity]: the respect sovereign nations afford each other by limiting the reach of their laws." Id at 2920. "Comity in this sense includes the choice-of-law principles that, in the absence of contrary congressional direction,' are assumed to be incorporated into our substantive laws having extraterritorial reach." Id.

s2 Id at 2910.

$* 3$ Justice Souter appeared to have taken great steps to limit the case's holding to its facts. See, for example, id at 2910 ("in the circumstances alleged here"); id at 2911 ("no need in this case to address other considerations"). Perhaps Justice Souter qualified his "true conflict" holding because of the procedural posture of the case. As the case came before the Court on a motion to dismiss on the pleadings, Justice Souter may have been hesitant to dismiss an extraterritorial antitrust case at such an early stage of litigation, before all the relevant facts were borne out.

It is also worth noting that two of the four Justices signing on to Justice Souter's opinion to give him a five-to-four majority, Justices White and Blackmun, have since left the Court.

${ }^{8}$ See Kenneth W. Dam, Extraterritoriality in an Age of Globalization: The Hartford 


\section{CRITIQUe OF THE CASE LAW}

As this historical review demonstrates, Timberlane clearly was the pivotal case both in its recognition of interest balancing as the prevailing international conflict of laws principle and in its wholesale recharacterization of the extraterritoriality analysis as a question of subject matter jurisdiction. Hartford Fire has only muddied the waters. This Section first critiques the preTimberlane principles of international conflict of laws, which no longer reflect the current international system. Second, this Section critiques Timberlane and its progeny (including Hartford Fire) for their espousal of the subject matter jurisdiction characterization of the extraterritoriality analysis. ${ }^{85}$

\section{A. Shortcomings of the Pre-Timberlane International Conflict of Laws Principles}

The prevailing principles of international conflict of laws have evolved alongside changing conceptions of the global reach of U.S. markets and international law. Courts risk undermining statutory policies when they apply principles of international conflict of laws which no longer reflect these realities of the international system. This was precisely the shortcoming inherent in the pre-Timberlane case law.

Initially, courts applied the strict territoriality principle set forth in American Banana. However, the application of this inflexible conflicts principle failed to further the central policy behind the antitrust laws: protecting U.S. markets from anticompetitive behavior. Under the strict territoriality principle, courts declined to regulate extraterritorial activities that affected competition in U.S. markets. Given increasingly internationalized world markets, this exemption of extraterritorial activities grew increasingly unacceptable.

Fire Case, 1993 S Ct Rev 289, 289 ("The case provided the opportunity for a murky and unsatisfactory doctrinal squabble between the Souter majority and the Scalia minority over the terminology and principles to be used in determining the extraterritorial applicability of a statute.").

${ }_{85}$ In addition to the antitrust field, the characterization issue and semantic confusion over the term "jurisdiction" also arise in the extraterritorial application of federal securities laws, where some courts have also framed the extraterritoriality analysis as one of subject matter jurisdiction, rather than legislative jurisdiction. See, for example, Psimenos $v$ E.F. Hutton \& Co., 722 F2d 1041, 1044-45 (2d Cir 1983) (outlining two alternative tests for subject matter jurisdiction, the "effects" test and the "conduct" test); Bersch $v$ Drexel Firestone, Inc., 519 F2d 974, 984-85 (2d Cir 1975). See generally Born and Westin, International Civil Litigation at 633-645 (cited in note 13). 
Courts reacted to this failure of the strict territoriality principle by shifting from American Banana's strict territoriality principle to the Alcoa effects test. International law had, in the intervening years, come to recognize Alcoa's "intended effects" test as a valid basis for the exercise of legislative jurisdiction. ${ }^{86}$

However, as U.S. commerce continued to expand globally, the effects test, while protecting U.S. competition, came under attack for failing to consider another policy that extraterritorial application implicates, namely U.S. foreign relations. Notably, foreign countries began to criticize the extraterritorial application of U.S. antitrust laws to activity within their territorial borders as infringements of their sovereignty. ${ }^{87}$ Foreign criticism was not limited to mere rhetoric, but harmed U.S. foreign relations. ${ }^{88}$ Thus, both American Banana's strict territoriality principle and Alcoa's "intended effects" test failed to adequately balance the policies of the antitrust laws with foreign policy concerns. Both are outmoded principles of international conflict of laws that fail to reflect modern changes in international markets and the international system. However, despite these deficiencies, Justice Souter's majority opinion in Hartford Fire reverts to the Alcoa "intended effects" test. ${ }^{89}$

\section{B. Flaws of Timberlane's Subject Matter Jurisdiction Characterization}

While Timberlane espoused a modern international conflict of laws principle-interest balancing - which addressed many of the limitations of the prior conflicts principles, the case also ushered in the sweeping recharacterization of the extraterritoriality analysis, soon adopted by many courts, including the Supreme Court in Hartford Fire. In addition to its radical departure from precedent ${ }^{30}$ this subject matter jurisdiction characterization suffers from several incurable defects: it is conceptually flawed, it is overly discretionary, and it is outcome determinative.

86 See The S.S. "Lotus" ("The Lotus") 1927 PCIJ (ser A) No 10 at 19 (recognizing the power of a state to legislate over conduct having an effect within that state's territory).

87 See Timberlane, 549 F2d at 609.

The United Kingdom, for instance, has enacted statutes forbidding compliance with U.S. extraterritorial antitrust proceedings and preventing enforcement of U.S. antitrust awards. See Born and Westin, International Civil Litigation at 600-03 (cited in note 13).

Hartford Fire, $113 \mathrm{~S} \mathrm{Ct}$ at 2909.

90 Compare American Banana, 213 US at 357; Alcoa, 148 F2d at 444. 
1. The subject matter jurisdiction characterization is conceptually flawed.

Framing the issue as one of subject matter jurisdiction has several inescapable conceptual flaws that do not comport with the underlying concept of federal subject matter jurisdiction. Courts adopting a subject matter jurisdiction characterization have interpreted the foreign commerce provision of the antitrust laws ${ }^{91}$ as establishing not only a substantive requisite for an antitrust violation, but a subject matter jurisdiction requisite as well. ${ }^{22}$ In other words, wholly separate from the necessity of an effect on U.S. foreign commerce needed for a substantive violation, these courts have held that such an effect must be established before a federal court may assert subject matter jurisdiction to hear the substantive allegations. ${ }^{93}$ Additionally, the subject matter jurisdiction characterization holds that international considerations factor into the subject matter jurisdiction determination as well, or at least inform a decision on whether to exercise such jurisdiction.

However, this characterization confuses the power of the federal courts with the power of Congress, entangling the respective powers of the two separate branches into the requirements for subject matter jurisdiction, an issue that solely concerns the power of the judiciary. In order to establish subject matter jurisdiction, both Article III of the Constitution and the congressional subject matter jurisdiction provisions ${ }^{94}$ require simply that the

91 See 15 USC $\S \S 1,2$ ("trade or commerce . . . with foreign nations").

92 One treatise explains the subject matter jurisdiction characterization as follows:

Since the Sherman Act requires a "restraint of trade or commerce . . . with foreign nations," some relationship between the restraint and foreign commerce must be present. This connection has two distinct facets, one jurisdictional, the other substantive. The jurisdictional facet focuses upon the question of whether the restraint at issue has a sufficient relationship to United States foreign commerce to justify regulation by Congress under the Commerce Clause. The substantive facet is concerned with whether the restraint is unreasonable and, therefore, in violation of the Sherman Act.

Earl W. Kintner, 1 Federal Antitrust Law $\$ 7.4$ at 304 (Anderson, 1980), quoting the Sherman Act, 15 USC $\$ 1$.

93 Courts have encountered similar questions regarding characterization in an analogous line of cases involving antitrust claims in the interstate commerce, as opposed to foreign commerce, context. See note 108.

94 There are three independent sources for federal court subject matter jurisdiction for cases "arising under" the federal antitrust laws: 28 USC $\S \S 1331,1337 ; 15$ USC § 15. See text accompanying notes 22-26. 
case arise under the federal antitrust laws, nothing more. Therefore, the subject matter jurisdiction characterization is flawed in requiring an effect on U.S. commerce to establish subject matter jurisdiction.

It was long ago settled in Bell $v$ Hood that subject matter jurisdiction is established under 28 USC $\S 1331$ if the plaintiff alleges nonfrivolous claims arising under the Constitution or federal law. ${ }^{95}$ Similarly, subject matter jurisdiction is established under 28 USC $\S 1337$ (and under 15 USC $\S 15$ ) if the plaintiff alleges nonfrivolous claims arising under the federal antitrust laws. The plaintiff need not prove the merits of the case to establish subject matter jurisdiction; ${ }^{96}$ subject matter jurisdiction does not depend upon whether the plaintiff's cause of action is one "on which [the plaintiff] could actually recover."97 Therefore, in nonfrivolous claims of extraterritorial antitrust violations, subject matter jurisdiction is not at issue. The power of federal courts to hear such cases is clearly established.

Whether extraterritorial activities affect U.S. commerce, in contrast, is an issue of Congress's power to regulate, which is governed by Article I of the Constitution and enacted through the substantive provisions of the Sherman Act. ${ }^{98}$ Both the limitations imposed by the Constitution and the restraints counseled by international law are limits on the power of Congress to legislate, not on the power of the federal courts. Article I of the Constitution, in which the Foreign Commerce Clause is found, is a delimitation of the "legislative Powers" of the United States federal government..$^{99}$ Section 8 of Article $I$ is a specific enumera-

${ }^{95} 327$ US 678, 681-83 (1946).

so Id. See also Duke Power Co. $v$ Carolina Environmental Study Group, Inc., 438 US 59,70 (1978). In fact, although courts repeatedly cite to Bell as the seminal case on this issue, the Supreme Court has consistently come to the same conclusion time and again. Justice Holmes held as early as 1913:

[G]ood or bad, the cause of action alleged is a cause of action [arising] under the laws of the United States. ... Conversely, when the plaintiff bases his cause of action upon an act of Congress [subject matter] jurisdiction cannot be defeated by a plea denying the merits of the claim. ... Jurisdiction is authority to decide the case either way. Unsuccessful as well as successful suits may be brought upon the act....

The Fair $v$ Kohler Die \& Specialty Co., 228 US 22, 25 (1913), cited in Bell, 327 US at 681. 57 Bell, 327 US at 682. See also Duke Power, 438 US at 70 (citing Bell).

${ }^{93}$ See 15 USC $\S \S 1,2$. These substantive provisions are distinct from the procedural provisions granting subject matter jurisdiction such as 15 USC \& 15 . Clearly, the additional grants of subject matter jurisdiction in 28 USC $\S 1331$ and 1337 are distinct from these substantive prohibitions as well.

${ }_{99}$ US Const, Art I, $\$ 1$. 
tion of these legislative powers within which Congress, and not the federal courts, must function.

In particular, the Commerce Clause ${ }^{100}$ limits the power of Congress to regulate anticompetitive behavior, both domestically and abroad. Domestically, the Interstate Commerce Clause ${ }^{101}$ limits Congress's power to regulate anticompetitive activities within the United States. For the activities to fall under the power of the federal government to regulate, they must "affect interstate commerce," as opposed to merely intrastate commerce. $^{102}$ In an analogous manner, the Foreign Commerce Clause $^{103}$ limits the power of Congress to regulate anticompetitive activities abroad. ${ }^{104}$ To fall under the power of the federal government, the extraterritorial activities must fall within the federal government's power to regulate U.S. foreign commerce. ${ }^{105}$

Moreover, in addition to constitutional constraints, to the extent that international considerations constrain government power, they temper congressional power to regulate extraterritorial conduct, not the power of the federal courts to hear such cases. The federal questions presented at the outset of an extraterritorial assertion of the antitrust laws are precisely whether application of the substantive provisions of the antitrust laws to

100 US Const, Art I, $\S 8, \mathrm{cl} 3$ ( ${ }^{c}$ The Congress shall have Power . . To regulate Commerce with foreign Nations, and among the several States ....").

${ }^{101}$ Id ("To regulate Commerce . . . among the several States . . . .").

102 See Gibbons $v$ Ogden, 22 US (9 Wheat) 1 (1824); Wickard v Filburn, 317 US 111, 124-25 (1942). The precise extent to which interstate commerce must be affected in the interstate antitrust context has been the subject of a slew of Supreme Court cases. See, for example, Hospital Building Co. $v$ Trustees of Rex Hospital, 425 US 738, 743-47 (1976); McLain $v$ Real Estate Board of New Orleans, Inc., 444 US 232, 241-47 (1980); Summit Health, Ltd. $v$ Pinhas, 500 US 322, $327-33$ (1991). The underlying concern of these cases is, of course, the limits imposed by the federal system on the powers of the central government. See Herbert Hovenkamp, Federal Antitrust Policy: The Law of Competition and its Practice \$ 21.1 at 694-99 (West, 1994).

${ }_{103}$ US Const, Art I, $\S 8$, cl 3 ("To regulate Commerce with foreign Nations . . . .).

104 See, for example, Montreal Trading Ltd. $v$ Amax Inc., 661 F2d 864, 869 (10th Cix 1981) ("The extraterritorial reach of American antitrust laws is limited [ ] to acts that affect trade or commerce among the several states or with foreign nations.").

${ }_{105}$ In the extraterritorial antitrust context, there are few federalism conflicts between federal and state governments. However, the Constitution nonetheless requires that federal regulation be based on Congress's delegated powers. This lack of federalism conflict in the foreign commerce context eases constitutional limitations on federal power. See Timberlane, $549 \mathrm{~F} 2 \mathrm{~d}$ at 609-10.

Moreover, the international limitations on U.S. power to regulate extraterritorial activities typically require a showing of effect within U.S. territory. Presumably, such a showing brings a regulation within Congress's power under the Foreign Commerce Clause as well. 
conduct abroad is within Congress's constitutional power to regulate foreign commerce (subject to international law limitations) and, if so, whether the anticompetitive activities at issue constitute an antitrust violation within the intent and purpose of Congress. Both issues question the reach of Congress's exercise of legislative jurisdiction, and neither can be answered until after the court has determined subject matter jurisdiction. The constitutionality and applicability of a statute to the facts of the case have nothing to do with the power of the federal court to hear the case.

It is entirely possible for a court to exercise its subject matter jurisdiction over the federal questions presented, only to find on the merits that the extraterritorial conduct is not within the scope of the antitrust laws. ${ }^{106}$ This would not be a belated determination that the court lacked subject matter jurisdiction in the first place to hear the case, but rather a determination on the merits that the antitrust laws do not prohibit the extraterritorial conduct because it is beyond the legislative jurisdiction and intent of Congress to regulate. ${ }^{107}$

Because the determination of subject matter jurisdiction should not be dependent upon proof of the merits of the case, courts' insistence on a finding of "intended effects" upon U.S. foreign commerce as a test of subject matter jurisdiction is misguided. ${ }^{108}$ Rather, the "intended effects" test of Alcoa is an issue

106 See The Fair, 228 US at 25 ("TT]here is [subject matter] jurisdiction whether the claim ultimately be held good or bad.").

107 Id. See also Bell, 327 US at 682.

108 In the analogous line of antitrust cases involving solely interstate, as opposed to foreign, commerce, the Supreme Court has openly struggled with the subject matter jurisdiction versus legislative jurisdiction characterization. Courts assuming a subject matter jurisdiction analysis similarly require an effect on interstate commerce, as opposed to simply intrastate commerce, for the courts to have subject matter jurisdiction to hear these cases. The requirement of effect on interstate commerce to establish "jurisdiction" (subject matter jurisdiction according to some of these courts, but what should properly be characterized as legislative jurisdiction) has evolved over the last twenty years. See Gulf Oil Corp v Copp Paving Co., 419 US 186, 199-203 (1974); Hospital Building Co., 425 US at 742-47; McLain, 444 US at 241-47; Summit Health, 500 US at 327-33. However, in none of these cases did the Supreme Court decide the question of the appropriate characterization of the interstate commerce provision. Both Gulf Oil and Hospital Building Co. explicitly left the question open as such a determination did not present itself. See Gulf Oil, 419 US at 203 n 19; Hospital Building Co., 425 US at $742 \mathrm{n}$ 1. The Courts in McLain and Summit Health employed the term "jurisdictional" but also did not make a definitive determination as to the proper characterization in the interstate commerce context. See generally Zenith Radio Corp v Matsushita Electric Industrial Co., Ltd., 494 F Supp 1161, 1173-74 (E D Penn 1980), for a critical review of the Supreme Court's avoidance of the characterization issue in the interstate commerce context. The district court, while feeling constrained by precedent to apply a subject matter jurisdiction analysis, argued persua- 
of legislative jurisdiction on the merits, which the court can reach only by recognizing and exercising subject matter jurisdiction over cases "arising under" the antitrust laws.

2. The subject matter jurisdiction characterization is overly discretionary.

Moreover, the subject matter jurisdiction characterization is inherently overly discretionary, and its analytic framework offers little guidance to courts. Under this analysis, the requirement of subject matter jurisdiction is solely within the court's discretion, guided only by notions of international comity. In the words of the Timberlane court, "jurisdictional' forebearance in the international setting is more a question of comity and fairness than one of national power." ${ }^{109}$ Courts are told to balance U.S. and foreign interests to determine whether extraterritorial application would promote both "fairness" (presumably to the overseas defendants) and international "comity."

However, subject matter jurisdiction is not within the discretion of the courts to exercise or decline, using nothing more than notions of international comity as a guide (as many courts espousing a two-pronged subject matter jurisdiction analysis have assumed). Neither Article III of the Constitution nor congressional statutes conferring subject matter jurisdiction to the federal courts in particular categories of cases delegates any discretion on the matter to the federal courts. The court must exercise its subject matter jurisdiction, if found to exist, as mandated jointly by the Constitution and Congress's subject matter jurisdiction statutes, to decide on the merits the international law and constitutional limitations on legislative jurisdiction. ${ }^{110}$

sively that the legislative jurisdiction characterization was more conceptually sound. Id at 1175-77. For commentators arguing the same, see Note, The Interstate Commerce Test for Jurisdiction in Sherman Act Cases and Its Substantive Applications, 15 Ga L Rev 714, 728-37 (1981); Comment, Sherman Act "Jurisdiction" in Hospital Staff Exclusion Cases, 132 U Pa L Rev 121, 126-30 (1983).

109 Timberlane, 549 F2d at 613 n 27.

110 Congress, and not the courts, decides in which categories of cases federal subject matter jurisdiction shall exist, and courts are obliged to carry out Congress's will. See New Orleans Public Service, Inc. $v$ Council of City of New Orleans, 491 US 350, 358-59 (1989). Justice Scalia, writing for the Court, stated that:

[F]ederal courts lack the authority to abstain from the exercise of jurisdiction that - has been conferred. For example: "We have no more right to decline the exercise of jurisdiction which is given, than to usurp that which is not given. The one or the other would be treason to the Constitution." 
3. The subject matter jurisdiction characterization has become outcome determinative.

Because of the highly discretionary nature of the subject matter jurisdiction characterization, its application inherently biases courts' extraterritoriality analyses and is therefore unacceptably outcome determinative. The subject matter jurisdiction analysis inherently shortchanges courts' reflection upon international considerations. A determination that foreign interests outweigh U.S. regulatory interests in applying the antitrust laws to extraterritorial conduct would entail the court's declining to exercise its subject matter jurisdiction. However, courts are understandably hesitant to decline to exercise congressionally mandated subject matter jurisdiction over claims arising under the antitrust laws. ${ }^{111}$ Thus, courts have often been predisposed to find that international (judicial) comity considerations do not counsel against exercising subject matter jurisdiction. ${ }^{112}$ This across-the-board bias inherent in the subject matter jurisdiction characterization has made the extraterritoriality analysis unduly outcome determinative, in favor of applying the federal antitrust laws extraterritorially. ${ }^{113}$

New Orleans Public Service, 491 US at 358, quoting Cohens $v$ Virginia, 19 US (6 Wheat) 264, 404 (1821). There are, however, extremely limited classes of cases in which federal courts do abstain. As Justice Scalia reasoned, these classes of cases are more properly understood as courts exercising discretion in withholding equitable relief, rather than abstaining from federal subject matter jurisdiction. New Orleans Public Service, 491 US at 359. Moreover, such abstention is "the exception, not the rule." Id.

Furthermore, these narrowly cabined classes of cases have all involved federalism concerns, which are not at issue in the extraterritoriality context. While the foreign relations concerns in extraterritorial antitrust cases are no less important, the legislative jurisdiction analysis espoused in this Comment fully incorporates international comity considerations. This obviates the need to carve out another "exception" to the rule that federal courts cannot abdicate subject matter jurisdiction mandated by Congress.

11 See Hartford Fire, $113 \mathrm{~S} \mathrm{Ct}$ at 2920 n 9 (Scalia dissenting).

112 For a scathing judicial critique of abstaining from the exercise of subject matter jurisdiction, see Laker Airways, Ltd. v Sabena, Belgian World Airlines, 731 F2d 909, 95051 (DC Cir 1984). See also James M. Grippando, Declining to Exercise Extraterritorial Antitrust Jurisdiction on Grounds of International Comity: An Illegitimate Extension of the Judicial Abstention Doctrine, 23 Va J Intl L 395, 421-27 (1983).

113 Indeed, the cases holding that international comity counsels in favor of declining to exercise subject matter jurisdiction under this discretionary approach are few and far between. Following Timberlane, Montreal Trading stands as one of the very few extraterritorial antitrust cases in which the court declined to exercise subject matter jurisdiction on international comity grounds. Montreal Trading Ltd. v Amax Inc., 661 F2d 864, 870-71 (10th Cir 1981). See also Laker Airways, 731 F2d at 950-51 (finding no cases in which subject matter jurisdiction was declined where there was more than a de minimis U.S. interest). 
Justice Souter's "true conflict" analysis in Hartford Fire took the pro-extraterritorial application bias a step further, making it even less likely that a court would find the antitrust laws not to apply to conduct abroad. ${ }^{114}$ Because Souter held that interest balancing kicks in, if ever, only if the defendant is bound by inconsistent foreign law, ${ }^{115}$ Hartford Fire suggests that U.S. antitrust laws presumptively apply to any and all extraterritorial conduct with substantial effects in the United States, unless the defendant can both prove a "true conflict" and convince the court that international comity counsels abstention from exercising its subject matter jurisdiction. An analysis so predisposed to find extraterritorial application raises grave concerns about the value of such an analysis in the first place.

\section{Proposal to Reassert an Updated Legislative JURISDICTION ANALYSIS}

As this critique of the case law has argued, on the one hand, the pre-Timberlane cases ${ }^{116}$ are insufficient as precedents for today's world in that the courts in those cases employed international conflict of laws principles that no longer adequately reflect developments in the international system. On the other hand, Timberlane and its progeny, in recharacterizing the extraterritoriality analysis as a question of the power of the federal courts, manifest insurmountable flaws inherent in their subject matter jurisdiction recharacterization. Therefore, this Comment proposes two shifts in the extraterritoriality analysis: first, that courts reestablish the legislative jurisdiction characterization, and second, that they update it to reflect modern principles of international conflict of laws.

\section{A. Reestablishing the Legislative Jurisdiction Analysis}

The conceptually sound characterization of the extraterritoriality issue is one of legislative jurisdiction. The power of courts to hear extraterritorial antitrust cases is rarely at issue, save for those instances in which a frivolous extraterritorial claim is alleged. Rather, the real concerns in these cases are substantive

\footnotetext{
$114113 \mathrm{~S}$ Ct at 2910.

115 Id.

116 See, for example, American Banana, 213 US at 357-58 (espousing the strict territoriality principle); Alcoo, 148 F2d at 443-44 (espousing the "intended effects" test).
} 
issues on the merits, including whether the antitrust laws reach the conduct abroad.

The legislative jurisdiction analysis clearly distinguishes between the requirements of subject matter jurisdiction and legislative jurisdiction. Under a legislative jurisdiction analysis, courts first establish subject matter jurisdiction (usually quite easily, since plaintiffs must only allege nonfrivolous claims "arising under" the federal antitrust laws). ${ }^{117}$ In fact, Congress has provided three independent, now-redundant sources for subject matter jurisdiction in claims "arising under" the federal antitrust laws. ${ }^{118}$

Second, having established the power to hear the cases, courts must exercise their mandated subject matter jurisdiction to determine the limits on Congress's exercise of legislative jurisdiction. This question involves whether congressional regulation of the extraterritorial activities is within the limits of the Constitution $^{119}$ and within the limits of international law, which Congress is presumed not to violate. ${ }^{120}$ This latter interpretive tool, also called the international law presumption, is relevant to determining the substantive reach of legislation such as the antitrust laws because customary international law incorporates limitations on a nation's exercise of legislative jurisdiction. ${ }^{121}$ Principles of both public and private international law recognize restrictions on exercising legislative jurisdiction extraterritorially. ${ }^{122}$ Public international law places limits on the val-

117 Courts may base subject matter jurisdiction on 28 USC $\S \S 1331,1337$, or on 15 USC § 15; all three independent bases are satisfied by nonfrivolous claims arising under the federal antitrust laws.

${ }_{118}$ As discussed above, none of these grants of subject matter jurisdiction requires any proof of effects on commerce, which is an issue of legislative jurisdiction to be determined on the merits.

119 In particular, courts must determine whether congressional regulation is within the limitations imposed by the Foreign Commerce Clause. See US Const, Art I, § 8, cl 3 .

120 "[A]n act of Congress ought never to be construed to violate the law of nations if any other possible construction remains." Murray $v$ Schooner Charming Betsy, 6 US (2 Cranch) 64, 118 (1804). See also Hartford Fire, 113 S Ct at 2919 (Scalia dissenting).

121 Restatement of Foreign Relations, Introductory Note to Part IV, ch 1, subch A at 235-37 (cited in note 5). See also Hartford Fire, $113 \mathrm{~S} \mathrm{Ct}$ at 2919 (Scalia dissenting).

122 Public international law refers to "the international legal principles that govern relations between sovereign nation-states." Born and Westin, International Civil Litigation at 5 (cited in note 13). Private international law, sometimes called "conflict of laws," refers to law "directed to resolving controversies between private persons, ... primarily in domestic litigation, arising out of situations having a significant relationship to more than one [nation-]state." Restatement of Foreign Relations $\$ 101$ comment c (cited in note 5). For more on the distinction between public and private international law, see Gary $B$. Born, A Reappraisal of the Extraterritorial Reach of U.S. Law, 24 L \& Policy Intl Bus 1, 
id bases for a nation's exercise of legislative jurisdiction in circumstances affecting the interests of other states. ${ }^{123}$ Private international law, moreover, has provided various international conflict of laws principles. ${ }^{124}$ Resolution of these legislative jurisdiction issues, however, are determinations on the merits. ${ }^{125}$

Not only does the legislative jurisdiction characterization overcome the conceptual flaws inherent in the subject matter jurisdiction characterization, it also prevents the extraterritoriality analysis from becoming overly discretionary and outcome determinative. While courts under a subject matter jurisdiction analysis are guided solely by their own discretion and notions of international comity, courts under the legislative jurisdiction characterization are directed in their interpretation of the antitrust laws by congressional intent and purpose which courts seek to ascertain. International considerations come into play, not as notions of fairness and comity, but as a presumption that Congress did not intend to transgress the prevailing principles of international conflict of laws.

Because the legislative jurisdiction characterization is not overly discretionary, courts adopting this characterization are not likely to discount international considerations. Courts seek to ascertain congressional purpose and intent, subject to the international law presumption. Viewing international law as a question of legislative jurisdiction narrows both the discretion and the

10-19 (1992).

${ }_{123}$ See Restatement of Foreign Relations, Introductory Note to Part IV, ch 1, subch A at $235-37, \S 402$ (cited in note 5).

124 Some commentators question the force of these international conflict of laws principles as international law. For a review and response, see Born, 24 L \& Policy Intl Bus at 16-19 (cited in note 122); Restatement of Foreign Relations $\$ 101$ comment c (cited in note 5) ("The concepts, doctrines, and considerations that inform private international law also guide the development of some areas of public international law, notably the principles limiting the jurisdiction of states to prescribe, adjudicate, and enforce law."), citing in particular $\$ \S 402,403$.

While this Comment argues that these international conflict of laws principles do indeed carry the force of international law, such that Congress should be presumed not to violate them, this debate is not central to the analysis. The international law nature of the international conflict of laws principles is merely used as an interpretive tool to ascertain the intent and purpose of congressional statutes. Even if not carrying the force of international law, that is, binding on nation-states, these conflict of laws principles are commonly recognized in the United States. Thus, courts may presume equally well in interpreting congressional statutes in the extraterritoriality context that, absent contrary intent, Congress has not violated these commonly recognized principles. In other words, whether having the force of international law or not, these international conflict of laws principles are the most reasonable background assumption of congressional intent and purpose.

${ }^{125}$ See Bell, 327 US at 682 . 
predispositions of courts under the subject matter jurisdiction analysis. In short, the legislative jurisdiction characterization overcomes all the flaws inherent in the Timberlane recharacterization as a question of subject matter jurisdiction. Moreover, a reassertion of the legislative jurisdiction characterization would represent a return to the pre-Timberlane precedents and the long-understood focus on legislative jurisdiction.

B. Updating the Legislative Jurisdiction Analysis with the Interest-Balancing Test

This Comment proposes a return to the legislative jurisdiction analysis, the only characterization that properly distinguishes between the power of Congress and the power of the federal courts. However, a mere return to the pre-Timberlane world of Alcoa's "intended effects" principle of international conflict of laws would not adequately reflect the realities of the evolution in international markets and the international system. Therefore, this Comment further proposes updating the legislative jurisdiction characterization by incorporating the now prevailing international conflict of laws principle of interest balancing. This Section demonstrates how the legislative jurisdiction framework established in this Comment readily accommodates the interest-balancing conflict of laws principle.

It is important to distinguish between the two remarkable innovations that the Timberlane court adopted: a subject matter jurisdiction characterization of the extraterritoriality analysis and an international conflict of laws principle of interest balancing. While the former obfuscates the concepts of subject matter jurisdiction and legislative jurisdiction, the latter represents an important recognition of the modern prevailing principle in the field of international conflict of laws. ${ }^{126}$

Timberlane's contribution to the evolution of international conflict of laws was an explicit recognition of international comity in the extraterritoriality analysis, balancing U.S. and foreign interests. Consideration of international comity furthered both the policy of protecting competition in U.S. markets as well as the countervailing policy of recognizing foreign interests by balancing the two against each other. Timberlane held that U.S. antitrust laws do not apply where the interests of foreign countries significantly outweigh the interests of the United States in

${ }^{126}$ See Restatement of Foreign Relations $\$ \S 402,403$ (cited in note 5). 
protecting competition in U.S. markets. ${ }^{127}$ In fact, the interestbalancing approach, or the "jurisdictional rule of reason," represents the latest step in the ongoing evolution of international conflict of laws principles-from strict territoriality ${ }^{128}$ to "intended effects" 129 to the modern day "jurisdictional rule of reason. ${ }^{130}$

However, Timberlane's two innovations, the flawed subject matter jurisdiction recharacterization and the welcomed recognition of foreign interests, need not go hand in hand. Indeed, the interest-balancing international conflict of laws principle espoused in Timberlane may be incorporated into a more conceptually sound legislative jurisdiction analysis, through application of a "jurisdictional rule of reason."

The Restatement of Foreign Relations offers considerable insight into how courts should employ the interest-balancing conflict of laws principle under a legislative jurisdiction analysis. ${ }^{131}$ While the Restatement itself does not delineate the respective roles of the federal courts and Congress, ${ }^{132}$ the modified

127 Note, however, that the Souter majority in Hartford Fire turned back to the preTimberlane international conflict of laws principle of Alcoa, the "intended effects" test. See text accompanying note 70 .

128 Applied under a legislative jurisdiction analysis in American Banana, 213 US at 357-58.

129 Applied under a legislative jurisdiction analysis in Alcoa, 148 F2d at 444.

130 Applied under a legislative jurisdiction analysis in Justice Scalia's dissenting opinion in Hartford Fire, $113 \mathrm{~S}$ Ct at 2918-20. See also Restatement of Foreign Relations §§ 402, 403 (cited in note 5).

131 See, in particular, $\$ \S 402$ and 403 and the accompanying comments and reporters' notes. See also $\S 415$, which seeks to apply the principles set forth in $\S \S 402$ and 403 to the context of antitrust cases.

Both the majority and dissent in Hartford Fire found support for their divergent characterizations of the extraterritoriality analysis in the provisions of the Restatement of Foreign Relations. Justice Souter construed the provisions to support both his subject matter jurisdiction characterization and his "true conflict" limitation on the use of international comity. Hartford Fire, $113 \mathrm{~S} \mathrm{Ct}$ at 2910-11, citing Restatement of Foreign Relations $\$ 403$ comment e, $\$ 415$ comment j. Justice Scalia's dissent, on the other hand, called for a legislative jurisdiction analysis and set forth a broad outline of this characterization based on the Restatement approach. See Hartford Fire, $113 \mathrm{~S} \mathrm{Ct}$ at 2921-22, citing Restatement of Foreign Relations \$ 403. This Comment builds upon the suggestion of Justice Scalia and locates the proper place of the Restatement's "jurisdictional rule of reason, ${ }^{n}$ or interest-balancing conflicts test, in the broader conceptual framework established in this Comment.

${ }^{132}$ The Restatement's primary concern is the limitation of international law on a nation-state's exercise of jurisdiction abroad, leaving the delineation of jurisdiction within the state to domestic considerations. In keeping with the framework proposed in this Comment, however, these international law limitations should be regarded as limitations on Congress's exercise of legislative jurisdiction, and not limitations on the power of the federal courts to hear extraterritorial cases. 
"jurisdictional rule of reason" test it sets forth fits well into the conceptual legislative jurisdiction framework proposed in this Comment.

The Restatement of Foreign Relations identifies two independent constraints imposed by international law on states' exercise of extraterritorial jurisdiction. ${ }^{133}$ The Restatement acknowledges that international law requires first a valid basis for the exercise of legislative jurisdiction, ${ }^{134}$ and second a requirement that such exercise not be unreasonable under international conflict of laws principles. ${ }^{135}$

First, $\S 402$ of the Restatement requires that a state have a valid basis under international law for exercising its legislative jurisdiction. International law recognizes three bases of legislative jurisdiction-territoriality, ${ }^{136}$ nationality, ${ }^{137}$ and most importantly, the effects principle: "[C]onduct outside its territory that has or is intended to have substantial effect within its territory." ${ }^{\prime 38}$ This effects principle, embodied in $\S 402$ of the Restatement as a valid basis for the exercise of legislative jurisdiction, closely resembles the "intended effects" test of Judge Hand in Alcoa. ${ }^{139}$

Second, even when there is a valid basis for the exercise of legislative jurisdiction, $\S 403$ of the Restatement requires that the exercise of extraterritorial jurisdiction not be unreasonable in international law and practice. ${ }^{140}$ Section 403 identifies a nonexhaustive list of factors, similar to the interest-balancing

${ }^{133}$ See Restatement of Foreign Relations $\S 403$ comment $g$ (cited in note 5) (U.S. statutes are to be interpreted only to the extent that they are consistent with these international law restraints.). See also Lowenfeld, 163 Recueil des Cours at 401-02 (cited in note 5).

${ }^{134}$ Restatement of Foreign Relations $\$ 402$ (cited in note 5).

135 Id $\S 403$.

${ }^{136}$ Id $\S 402(1)$.

${ }^{137}$ Id $\S 402(2)$.

${ }^{138}$ Id $\S 402(1)(c)$. The Restatement recognizes the controversy surrounding the extraterritorial extension by the United States of its economic regulation, in particular through the federal antitrust laws. Despite the controversy, the Restatement acknowledges that "international law does not preclude jurisdiction in such instances, subject to the principle of reasonableness [in § 403]." Id $\S 402$ comment $d$.

139148 F2d at 444 . As explained above, the source of both Judge Hand's test in Alcoo and the Restatement's effects principle is The S.S. "Lotus" ("The Lotus"), 1927 PCIJ (ser A) No 10 at 19 (recognizing the power of a state to legislate over conduct having an effect within that state's territory). Note, however, that the Restatement's rendition of the effects principle adds a requirement of substantiality, not part of the Alcoa formulation. See text accompanying note 138 .

${ }^{140}$ See Restatement of Foreign Relations $\S 403(1)$ (cited in note 5). 
tests of the Timberlane ${ }^{141}$ and Mannington Mills ${ }^{142}$ line of cases, which the field of international conflict of laws recognizes as establishing unreasonableness. ${ }^{143}$ It is clear, however, that where Timberlane and subsequent courts assuming a subject matter jurisdiction analysis regarded interest balancing as a question of judicial comity, ${ }^{144}$ the Restatement's understanding of international law considers reasonableness as a question of legislative jurisdiction, or legislative comity. ${ }^{145}$

Because the Restatement's "jurisdictional rule of reason" represents the prevailing international conflict of laws principle, courts would ascertain, on the merits, congressional intent and purpose under the presumption that Congress did not intend to violate international law. Therefore, courts would look first at the Alcoa "intended effects" test to determine whether, under the circumstances, Congress had a valid basis for the exercise of legislative jurisdiction. Second, courts would determine whether

141549 F2d at 614 . See note 46 for the list of seven factors espoused in Timberlane.

${ }^{142} 595$ F2d at 1297 (applying a similar list of ten factors).

143 Restatement of Foreign Relations $\$ 403$ (cited in note 5).

144 See Timberlane, 549 F2d at 613 n 27; Mannington Mills, 595 F2d at 1296 ("When foreign nations are involved..., limitations of judicial power are considerations that should have a bearing on the decision to exercise or decline jurisdiction.").

${ }^{145}$ While the Restatement exemplifies Timberlane and Mannington Mills (cases espousing subject matter jurisdiction characterizations) as judicial applications of its principle of reasonableness, see reporters' notes to $\S 415$, the comments strongly suggest the preference for a legislative jurisdiction analysis. See, for example, $\S 403$ comment a:

Legislatures and administrative agencies, in the United States and in other states, have generally refrained from exercising jurisdiction where it would be unreasonable to do so, and courts have usually interpreted general language in a statute as not intended to exercise or authorize the exercise of jurisdiction in circumstances where application of the statute would be unreasonable.

These unqualified references to "jurisdiction" imply reference to legislative jurisdiction and not the power of federal courts to hear such cases.

See also Justice Scalia's dissent in Hartford Fire:

The "comity" they refer to is not the comity of courts, whereby judges decline to exercise jurisdiction over matters more appropriately adjudged elsewhere, but rather what might be termed "prescriptive [or legislative] comity": the respect sovereign nations afford each other by limiting the reach of their laws. That comity is exercised by legislatures when they enact laws, and courts assume it has been exercised when they come to interpreting the scope of laws their legislatures have enacted. ... Comity in this sense includes the choice-of-law principles that, "in the absence of contrary congressional direction," are assumed to be incorporated into our substantive laws having extraterritorial reach.

$113 \mathrm{~S} \mathrm{Ct}$ at 2920 (Scalia dissenting). 
such an exercise of legislative jurisdiction would be reasonable in international law. ${ }^{146}$ Thus, a legislative jurisdiction analysis, incorporating the Restatement's "jurisdictional rule of reason" limitation of international conflict of laws, would mark a return to the pre-Timberlane characterization of the extraterritoriality analysis, not an approach entirely alien to federal courts. ${ }^{147}$

However, one of the underlying justifications for the subject matter jurisdiction characterization seems to have been an effort to keep remote cases from becoming embroiled in litigation in U.S. courts. ${ }^{148}$ In reality, though, even under a subject matter jurisdiction analysis, such quick disposition is rare, ${ }^{149}$ and any practical benefits of such an approach must be questioned. To counter the criticism that a legislative jurisdiction analysis would

${ }_{145}$ Justice Scalia would add a threshold presumption against extraterritoriality to the Restatement's analysis of legislative jurisdiction: "[L]egislation of Congress, unless a contrary intent appears, is meant to apply only within the territorial jurisdiction of the United States." Hartford Fire, $113 \mathrm{~S} \mathrm{Ct}$ at 2918, quoting EEOC $v$ Arabian American Oil Co., 499 US 244, 248 (1991). However, Scalia reluctantly conceded that this presumption had been overcome with respect to the federal antitrust laws, not through contrary congressional intent, but through judicial precedent. Hartford Fire, $113 \mathrm{~S} \mathrm{Ct}$ at 2918.

However, in light of the international law presumption and the updated legislative jurisdiction analysis proposed in this Comment, the additional threshold presumption of Aramco that Scalia espouses is unnecessary. Aramco argues that the presumption against extraterritoriality "serves to protect against unintended clashes between our laws and those of other nations which could result in international discord." 499 US at 248. However, the international law presumption itself already fully considers the potential for conflict with foreign nations by presuming that Congress did not intend to violate international law, including the modern international conflict of laws principle: the Restatement's "jurisdictional rule of reason." Because the Restatement requires both a valid basis in international law for the exercise of legislative jurisdiction in international law and a further limitation of reasonableness, the need for a turn-of-the-century territoriality presumption to avoid serious foreign relations conflicts is both outmoded and redundant. The interest-balancing principle incorporated into the Restatement is specifically geared to avoid such "unintended clashes" by weighing both U.S. and foreign interests. For a comprehensive review of the erosion of the territoriality principle and an argument calling for its abandonment, see Born, 24 L \& Policy Intl Bus at 21-79 (cited in note 122).

${ }^{147}$ In the extraterritorial antitrust context, the legislative jurisdiction analysis was applied from the outset by courts such as American Banana, 213 US at 357-59, and Alcoa, $148 \mathrm{~F} 2 \mathrm{~d}$ at 443. Moreover, as Justice Scalia pointed out in his dissent in Hartford Fire, $113 \mathrm{~S} \mathrm{Ct}$ at 2921-22, the Supreme Court has recognized the appropriateness of the legislative jurisdiction analysis of the extraterritoriality issue in numerous contexts outside the antitrust field. See, for example, the maritime trilogy of Lauritzen $v$ Larsen, 345 US 571, 576-83 (1953); Romero v Intl Terminal Operating Co., 358 US 354, 381-85 (1959); and McCulloch $v$ Sociedad Nacional de Marineros de Honduras, 372 US 10, 20-22 (1963).

${ }_{148}$ See Atwood and Brewster, Antitrust and American Business Abroad $\$ 6.14$ at 168 (cited in note 62).

${ }_{149}$ For example, Timberlane took almost a decade of appeals and remands to determine that the court did not have the power to hear the case under the subject matter jurisdiction analysis that the court adopted. See Timberlane Lumber Co. $v$ Bank of Ameri$c a, 749$ F2d 1378, 1379-81 (9th Cir 1984) (documenting the case's extensive history). 
tie up remote cases in extended litigation for an even longer period of time, courts must shape the legislative jurisdiction analysis of the extraterritoriality issue to dispose expeditiously of claims having little relation to U.S. regulatory interests. Courts could gear pre-trial discovery and the disposition of issues at the outset of trial solely toward the international conflict of laws question. Courts would therefore spend more time focusing on the limitations on legislative jurisdiction, namely the need for a valid basis for legislative jurisdiction under the effects test and a reasonable basis under the "jurisdictional rule of reason." Structuring case disposition in this manner would dispose of tangential cases just as quickly as under the subject matter jurisdiction characterization, yet would be based on a more conceptually sound approach.

Not only does the legislative jurisdiction characterization of the extraterritoriality issue lead to greater conceptual clarity of the underlying principles, but it also has significant practical implications. The most obvious procedural implication of a legislative jurisdiction characterization is that the limitations imposed by the Constitution and international law would be issues to be determined on the merits. Therefore, dismissal would be appropriate under FRCP 12(b)(6) for failure to state a claim upon which relief may be granted, under FRCP 56 for summary judgment, or under FRCP 50 for directed verdict, rather than under FRCP 12(b)(1) for lack of subject matter jurisdiction. Framing the extraterritoriality analysis as a question of legislative jurisdiction, as opposed to subject matter jurisdiction, also has significant procedural ramifications for burden of proof, pendent jurisdiction, the appropriate standard of appellate review, res judicata effects, and waivability. ${ }^{150}$ In other words, the analysis proposed in this Comment carries with it all the procedural ramifications of properly characterizing the extraterritoriality analysis as a question of legislative jurisdiction, a determination on the merits, as opposed to a nonviable issue of subject matter jurisdiction.

\section{CONCLUSION}

Because the subject matter jurisdiction characterization assumed by the Timberlane and Hartford Fire courts suffers from

150 Detailed appraisal of these procedural ramifications is outside the scope of this Comment; they are raised merely to notify readers of many of the practical implications that a return to a legislative jurisdiction characterization would entail. 
inherent conceptual flaws, this Comment advocates a return to the legislative jurisdiction characterization. Moreover, because interest balancing and the "jurisdictional rule of reason" reflect the prevailing modern international conflict of laws principles, this Comment advocates updating the legislative jurisdiction analysis to reflect these developments. These principles of international law and international conflict of laws have not remained static. Instead, they remain quite dynamic and have gradually evolved over time, reflecting transformations in the nature and level of transnational activity and perceptions in the way nations interact in the international system. ${ }^{151}$

Courts are now faced with a new generation of international conflict of laws principles that more realistically reflect the modern world. However, regardless of the applicable international conflict of laws principles, the analytic characterization of the extraterritoriality analysis should focus on legislative jurisdiction rather than subject matter jurisdiction. Principles of international law and international conflict of laws continue to restrain Congress's exercise of legislative jurisdiction. Courts should continue to presume in interpreting the extraterritorial scope of the federal antitrust laws (as Holmes did in American Banana and Hand did in Alcoa) that Congress did not intend to violate principles of international law, including the prevailing principles of international conflict of laws. Although the principles of strict territoriality and "intended effects" each had their day, the "general and almost universal"152 international conflict of laws principle prevailing today is the "jurisdictional rule of reason" embodied in the Restatement. 
